\title{
Examination of vertical green systems in educational buildings: a field study in Çukurova University
}

\author{
Ülkü Şimşek* (1) \\ Özlem Şenyiğit $* *$ (1)
}

\begin{abstract}
The concept of sustainability, which is currently sitting on our agenda with increasing environmental pollution has gradually increased its importance. In order to leave a livable ecosystem for new generations, it is essential that individuals are given the necessary education within the scope of the issues that need to be done. The best training is hands-on training. A person can internalize the concept that he sees, touches, feels in the environment in which he is located, that is, lives with all his perceptions. In this case, building educational structures with the goals of sustainable architecture is an important step in terms of instilling the concept of sustainability in the younger generations. In the context of sustainable design, vertical green systems have taken an important place with the technological developments in recent years and it has been shown that they contribute to achieving sustainable design goals. It is believed that the application of these systems in school structures will make it easier for students to explain the concept of herd, because they are experiential. For these reasons, the aim of the study is to reveal the benefits of vertical green systems in terms of sustainability in educational structures and to present a study that can provide resources for sustainable school designs.In the study, the benefits of vertical green systems were discussed in the context of reducing the urban heat effect, improving air quality, absorbing noise and saving energy. Energy analysis was carried out through revit program by applying vertical green system to the educational buildings selected from Adana Çukurova University in order to demonstrate the benefits of vertical green systems within the scope of energy conservation with data. As a result of the evaluations made, the electrical energy savings of green vertical systems were revealed with numerical data and the criteria to be considered for an environmentally beneficial vertical green system application were explained.
\end{abstract}

Keywords: vertical green system, educational building, energy analysis.

\section{Introduction}

Today, environmental pollution and deteriorating natural balances threaten the entire world ecosystem. Whether many of the resources we have will exist in the future is considered from different perspectives and is a subject of discussion. In this context, the concepts of "sustainability" and "sustainable architecture" come to the fore. Sustainability refers to a balance that adapts to human needs without reducing the productivity of health and natural systems (Mendler and Odell, 2000). AIA (American Institute of Architects) defines the concept of sustainability as: "the continuity

*(Corresponding author) Msc. Arch., Çukurova University, Turkey, \ulkusimsek4455@gmail.com **Assist. Prof. Dr., Çukurova University, Turkey, ozlemsenyigit@gmail.com / This is an open access research article under the CC BY NC license / Article history: Received 29 Oct. 2020, Accepted 23 Nov. 2020, Published 29 Dec. 2020. ***This article is based on the MSc thesis entitled 'Eğitim Yapılarında Dikey Yeşil Sistemlerin Incelenmesi: Çukurova Üniversitesi Özelinde Alan Çalışması' that was conducted within Ç.U. Master of Architecture Program in 2018. 
of the future functionality of the society without disrupting the balance regarding the depletion or overload of the basic resources needed by the system" (AIA, 2007).

It is imperative to provide individuals with the necessary education within the scope of the issues that need to be done in order for the balance of nature to continue without disruption, to be protected, and to be transferred to future generations in a livable manner. In order to achieve this, firstly, education policies aiming at raising conscious individuals should be formed. Afterwards, it is necessary to go beyond adding the sustainability issue to the education curriculum and to design the educational structures themselves in line with sustainable goals. Sustainable design goals include increasing air quality with natural ventilation, providing energy efficiency, waste management, and water conservation.

With the technological developments in recent years, vertical green systems have taken an important place within the scope of sustainable design, and it has been demonstrated that they contribute to achieving sustainable design goals. It is thought that the application of these systems in school buildings will make it easier to explain the concept of sustainability to the students due to their experiential nature. If vertical green systems are applied to the building, the benefits in terms of sustainability can be summarized as follows: It regulates the microclimate by reducing the average temperature of the environment and decreases the wind speed, it absorbs solar radiation and plants can reduce solar radiation with the effect of evaporation, which regulates humidity levels and surface temperatures. Also, vegetation provides building energy saving. For these reasons, sustainable education building design, which does not ignore environmental problems, was supported and the benefits of vertical green systems, when applied to educational buildings, were examined. The study also evaluated the effects of these systems on heating and cooling loads on educational buildings and their energy performance.

\section{Basis of Study}

The population in the world is increasing rapidly, and this increase brings along some problems with it. This rapid increase in the urban population causes the growth of cities and the construction excessive number of buildings. This increases the loss of green space gradually. Frequently encountered applications such as sustainable active systems, passive systems, integration of these systems into the design, green roof systems are practices aimed at replacing lost green space and solving these environmental problems. Vertical green systems are one of these applications. However, especially in our country (Turkey), there is an insufficiency regarding the application of vertical green systems, and its benefits to the environment are not exactly known.

Even if sustainable design practices are sufficient in number and quality, they will not provide a complete solution to environmental problems. It will be possible to be able to speak of success in achieving sustainable goals only through raising awareness of our people on this issue. In this respect, it is important to create education policies in line with sustainable goals. As Şahin EB, Dostoğlu N. stated; "Ensuring awareness of sustainability is attached utmost importance by educators, and "education for sustainability" programs are included in all levels of education starting from pre-school education so that children can learn the gains of this perspective at an early age. As a supporter of this understanding, it is thought that educational buildings themselves should be a laboratory where theoretical knowledge taught in schools can be experienced" (Şahin and Dostoğlu, 2015). It is believed that the application of vertical green systems, which are among the sustainable design solutions, in educational buildings will enable students to experience their theoretical knowledge since these systems will be directly observed. The thought that vertical green system applications, which we encounter frequently around the world, are not attached to the 
importance they deserve in our country has been one of the factors that formed the basis of the study. In this respect, examples of vertical green systems applied in educational buildings were examined in the study, and it was aimed to demonstrate the benefits of vertical green systems within the scope of sustainability by simulating it.

\section{Scope of Method}

In the study, examples of vertical green systems applied in educational buildings were examined, and the benefits they provided in terms of sustainability were tried to be revealed. In this context, within the scope of the study, the answers to the questions,

- What is the concept of sustainability and sustainable architecture, and why are they important?

- What is a vertical green system within the scope of sustainable architecture? What benefits does it provide?

- What are the needs of educational buildings in terms of sustainability?

- What are the place and benefits of vertical green systems in educational buildings? were sought by the literature review method.

In the study, the benefits brought about by the application of vertical green systems examined within the scope of sustainable design in educational buildings were investigated. Within the scope of these benefits, the effect of vertical green systems on energy conservation was aimed to be revealed with data, and fieldwork was carried out for this purpose. Fieldwork was carried out at Çukurova University in Adana province in Turkey. Since the benefits of vertical green systems according to their facade directions were aimed to be compared, two educational buildings with similar facade proportions but differently positioned were selected. The study was carried using the Revit program on the BIM platform.

In order to perform the energy analysis of the buildings selected in the Revit program, a modular living wall system, whose modules can be supplied when an addition is needed and can be changed regularly, was preferred as a vertical green system type. The system provides ease of maintenance and enables repair in case of any malfunction. The modular living wall system type that was chosen was applied along the north and south facades of the A-block building of the Faculty of Economics and Administrative Sciences, whose north and south facades were wider. The east and west facades of the R2 classrooms building were wider, so the living walls were applied to the east and west facades of the building. Afterwards, the energy analysis of the buildings was made in the Revit program.

\section{Literatur Review}

\subsection{Sustainability and Sustainable Architecture}

Sustainability, in its dictionary meaning, is "the method of harvesting and/or using a resource so that the resource is not depleted or permanently damaged" (Merriam-Webster, 2002). The most common definition of sustainability was made in the Brundtland report as "Meeting the needs of today without compromising the opportunity of future generations to meet their own needs" (Brundtland, 1987). As Sylvan and Bennett (1994) pointed out in their work, being more green necessitates some commitment on the part of humans to limit or reduce their environmental impact on the world or its regions. This means that one of the following should be done in the future: reduction of the human population, or the majority of people adopting a lifestyle that has less impact on the environment or advances in technology to reduce the overall impact (Sylvan and Bennett, 1994). For these reasons, we should look for ways to transfer our resources to future generations, bearing in mind the deteriorating natural balances and the endangered world 
ecosystem. At this point, the concept of sustainability gets into our agenda and is frequently discussed today.

The buildings, which are the products of architecture, and the building sector consume most of the resources produced in the world compared to other human activities, and indirectly have a great impact on issues such as global warming, acid rain, and excessive accumulation of waste. Buildings cover $10 \%$ of global economic activities, consume $40 \%$ of material and energy production in the world, are responsible for $17 \%$ of freshwater consumption and use $25 \%$ of annual global wood production (Curran, 2000). Since the construction sector is the only sector that has such a great impact on the global environment, it is a necessity to improve the environmental impacts of all building-related activities. In this context, the issue of creating a widespread awareness about environmentally sensitive and sustainable architecture and construction comes to the fore as the only solution in the field of contemporary architecture.

\subsection{Vertical Green Systems in Sustainable Architecture and Their Historical Development}

The concept of green walls refers to all systems which enable greening a vertical surface (e.g., facades, walls, blind walls, partition walls, etc.) with a selection of plant species, including all the solutions with the purpose of growing plants on, up or within the wall of a building (Manson and Castro-Gomes, 2014). Today, green systems are not just green surfaces covered with plants. Green systems are green walls and roofs used as passive cooling systems that can increase the scale of greenery in the city. Green walls and roofs contribute to vegetation throughout the urban environment. The first green wall can be traced back to the 11th century and the Vikings' period. The Vikings used stones, timber, and peat bricks to construct their habitations. Peat is an accumulation of partially decayed vegetation matter; it is formed in swamps or similar environment. When the Vikings used peat brick, grass naturally grew on this organic material. The habitation was therefore covered with vegetation (Bjerre, 2011).

In the 1920s, Britain - through the well-known "Green City Movement" - and North America promoted trellis structures and self-climbing plants on houses and gardens, but the greatest evolution occurred in 1988, when the French botanist Patrick Blanc, who is the inventor of the Vertical Garden (Mur Végétal), started to use stainless steel cable system for green facades. Patrick Blanc introduced a controlled environment where the plants were in contact with neither the wall nor the soil. Load-bearing walls don't need to be stronger because the metal frame carries the load of the installation (Papadopoulou, 2013). An important "point of reference" to the evolution of the green wall systems is 300 green wall panels translated into $3,500 \mathrm{~m} 2$ of the planted wall became the landmark of the EXPO 2005 in Japan. (Papadopoulou, 2013) (Photo 1).

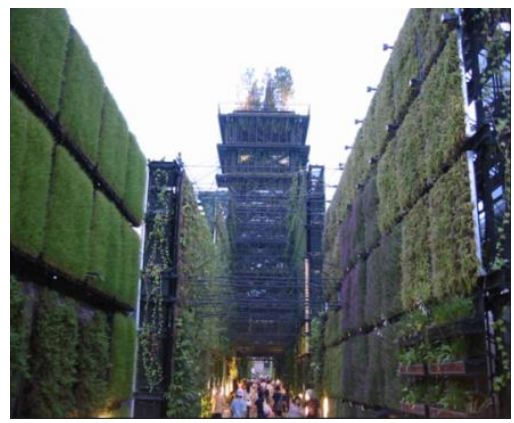

Photo 1 Bio Lung, Expo 2005 Aichi Japan World Fair (URL-1) 


\subsubsection{Vertical Green System Design Criteria}

"In the design of greening systems, many issues such as integration with the building, sustainable material selection, environmental impact and symbiosis between the growth environment and vegetation, economy-related to costs and potential savings should be taken into account (Perini, Ottele, Haas, Raiteri, 2013). In addition to these, the most important point to be considered in a vertical green system design is the facade features of the building. It is important to know the parameters of the facade and to design accordingly in order to make a design suitable for the climate in a vertical green system to be applied. The compactness-gap ratio of the facade, whether it is terraced or not, its location relative to other buildings' facades, the facade direction, the features of the facade shell, and the solar control applied on the facade are parameters related to the facade. Among green facade types, cable, wire, mesh, net system, or modular cage system can be applied. Microclimatic benefits of these systems to the building will be in the form of shading the windows and decreasing air temperature and surface temperature (Table 1).

Table 1 Process tree for green facades and living wall systems (Perini et al., 2013)

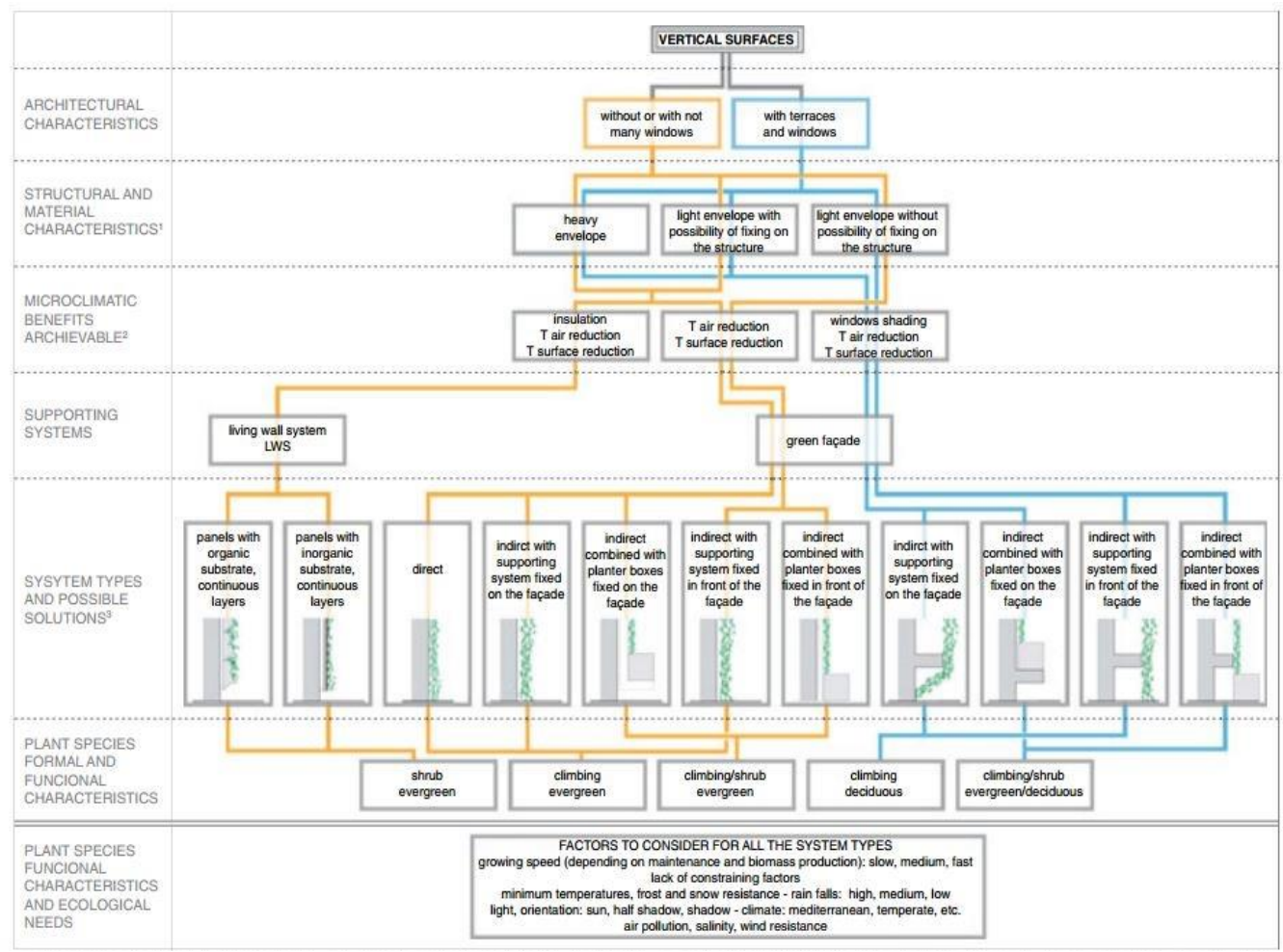

\subsection{Classification of Vertical Green Systems}

There are various classifications of vertical green systems in the literature according to their structural designs, application areas, growth environments, and plant species. As a result of the examination of all types of vertical green systems that are classified according to different criteria, groupings of vertical green systems, application methods, structural designs, and classifications according to plant species were brought together in an effort to form a holistic table in order to provide a guide for future studies (Table 2). 
Table 2 Classification of vertical green systems (prepared by the author)

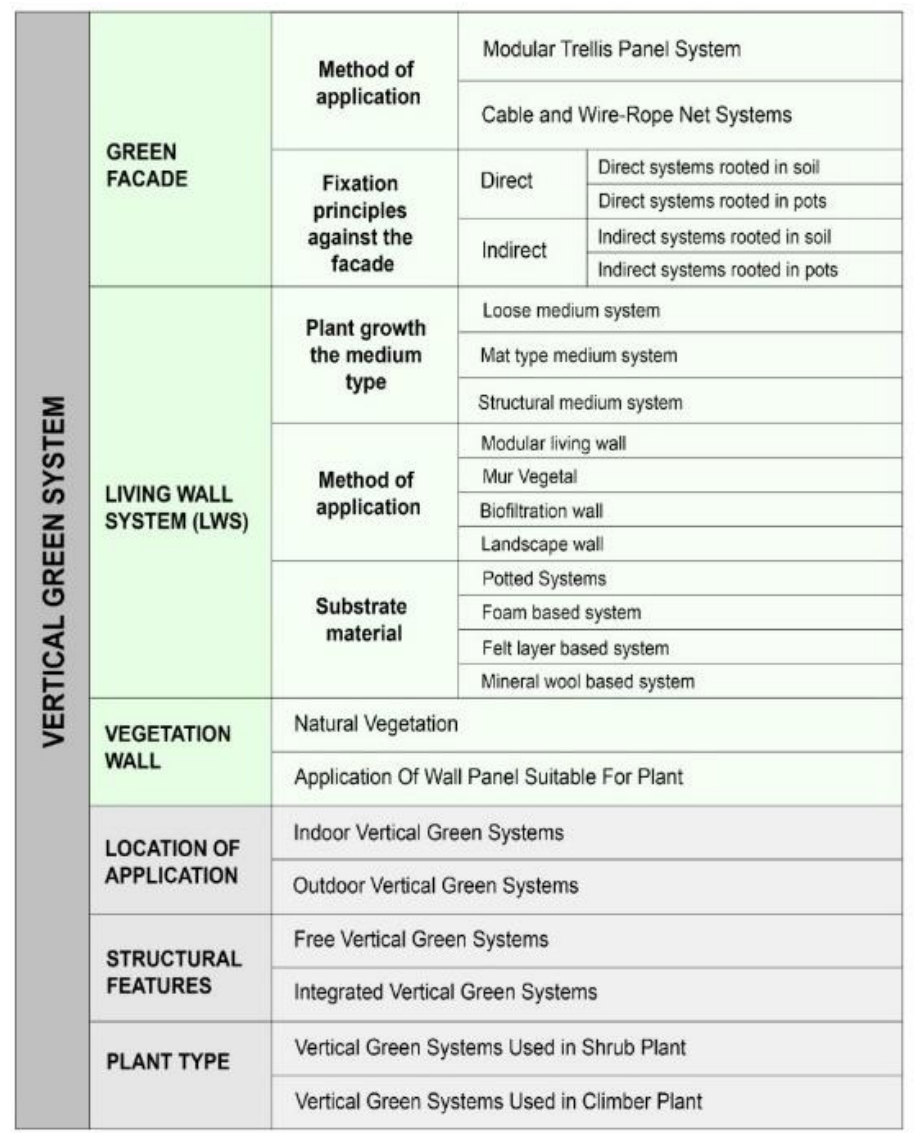

\subsubsection{Green Facades}

Green facades are a type of green wall system in which climbing plants or cascading ground covers are trained to cover specially designed supporting structures. Green facades can be anchored to existing walls or built as freestanding structures, such as fences or columns (URL-2). Green facades are classified according to their application and the principles of fastening to the facade (Table 3) (Figure 1).

Table 3 Green facade classification

\begin{tabular}{|c|c|c|c|}
\hline \multirow{6}{*}{$\begin{array}{l}\text { Green } \\
\text { Facades }\end{array}$} & \multirow[t]{2}{*}{$\begin{array}{l}\text { Green Facades } \\
\text { According to } \\
\text { Application } \\
\text { Type }\end{array}$} & \multicolumn{2}{|c|}{$\begin{array}{l}\text { Modular Trellis Panel System: } \\
\text { The building block of this modular system is a rigid, light-weight, three-dimensional panel made } \\
\text { from a powder-coated, galvanized and welded steel wire that supports plants with both a face } \\
\text { grid, and a panel depth. This system is designed to hold a green facade off the wall surface } \\
\text { (Papadopoulou, 2013). }\end{array}$} \\
\hline & & \multicolumn{2}{|r|}{$\begin{array}{l}\text { Cable and Wire-Rope Net Systems } \\
\text { Such systems are more suitable for the support of faster-growing plants with denser foliage (via } \\
\text { grids) than for slower climbers. (GRHC, 2008). }\end{array}$} \\
\hline & $\begin{array}{l}\text { Green Facades } \\
\text { According to } \\
\text { the Fixing }\end{array}$ & \multirow{4}{*}{ Direct } & $\begin{array}{l}\text { Direct vegetation rooted in the soil } \\
\text { Such green facades rooted in the ground take nutrients and water from the soil and } \\
\text { grow by climbing the structure (Mir, 2011). }\end{array}$ \\
\hline & $\begin{array}{l}\text { Principle on the } \\
\text { Facade }\end{array}$ & & $\begin{array}{l}\text { Direct vegetation rooted in pots } \\
\text { In direct vegetation rooted in pots, the plant is planted in prepared pot systems, not } \\
\text { directly on the ground, and the plant grows again by climbing the structure (Mir, 2011). }\end{array}$ \\
\hline & \multirow{2}{*}{ Indirect } & & $\begin{array}{l}\text { Indirect vegetation rooted in the soil } \\
\text { For the plant species, specially designed support systems can be applied to allow the } \\
\text { plants to grow on the structure and cover the facade (Mir, 2011). }\end{array}$ \\
\hline & & & $\begin{array}{l}\text { Indirect vegetation rooted in pots } \\
\text { The plant planted in pot systems grows on the above-mentioned modular cage panel } \\
\text { systems and cable and wire mesh network systems (Mir, 2011). }\end{array}$ \\
\hline
\end{tabular}




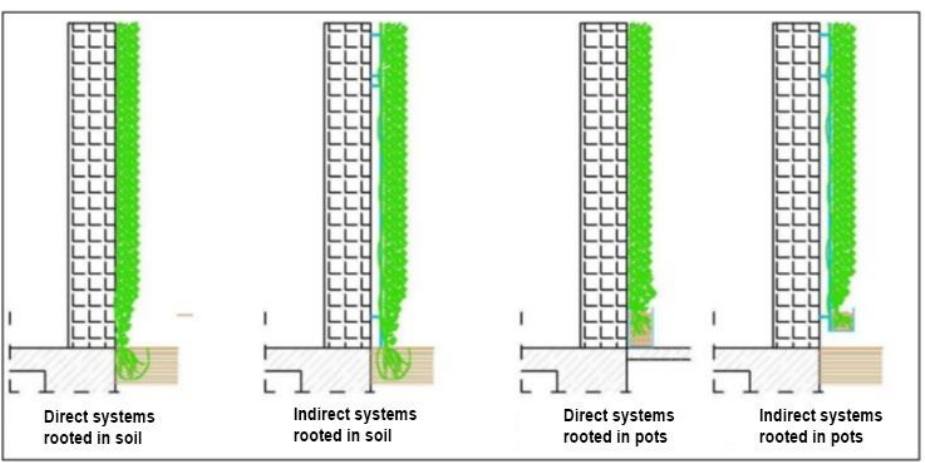

Figure 1 Green facade types (Mir, 2011)

\subsubsection{Living Wall System (LWS)}

Living walls; they are "living walls" specially constructed to provide a vertical growing surface for plants using. The base structure of a simple living wall consists of an irrigation system in a form of pipes, a corresponding framework which plays the role of a supporting system and stainless steel panels which contain the growing (or growth) medium. A living wall system (also referred to as a bio-wall, ecowall or vertical garden) differs from green facade in that it can be installed almost anywhere in or upon a building and may be freestanding or attached to an existing wall. It is typically more permanent and is composed of a structural framework supporting a layered assembly or modular panels that contain a growing medium - such as packed soil, fiber mats, or some other substrate - and an integrated irrigation system that cycles water through the panels as needed. (URL-3), (Figure 2), (Tablo 4).

Table 4 Living wall classification

\begin{tabular}{|c|c|c|}
\hline \multirow{11}{*}{$\begin{array}{l}\text { Living } \\
\text { Walls } \\
\text { (LWS) }\end{array}$} & \multirow{3}{*}{$\begin{array}{l}\text { To Plant } \\
\text { Growth } \\
\text { Environment }\end{array}$} & $\begin{array}{l}\text { Loose medium system Loose medium systems consist of a shelf ("soil-on-a-shelf" type } \\
\text { system) or bag ("soil-in-a-bag" type system) installed onto a wall after being filled with soil. }\end{array}$ \\
\hline & & $\begin{array}{l}\text { Mat type medium system Mat media are quite thin, and as a result, they cannot support the } \\
\text { growth of mature plants for more than } 5 \text { years (Bjerre, 2011). }\end{array}$ \\
\hline & & $\begin{array}{l}\text { Structural medium system It is the most robust option in terms of living walls as they have a } \\
\text { lifespan of 10-15 years and perform well in areas where high winds, seismic activity or heights } \\
\text { need to be addressed during the design process (Papadopoulou, 2013). }\end{array}$ \\
\hline & \multirow{4}{*}{$\begin{array}{l}\text { According to } \\
\text { the } \\
\text { Application } \\
\text { Type }\end{array}$} & $\begin{array}{l}\text { Modular Living Wall System It is an evolution of green roof applications using modules. It } \\
\text { consists of panels of different geometries that hold the growth medium. }\end{array}$ \\
\hline & & $\begin{array}{l}\text { Mur Vegetal The 'Mur Vegetal' is a unique form of green wall pioneered by Patrick Blanc. It is } \\
\text { composed of two layers of synthetic fabric with pockets that physically support plants and } \\
\text { growing media (GRHC, 2008). }\end{array}$ \\
\hline & & $\begin{array}{l}\text { Biofiltration wall An 'active' living wall is intended to be integrated into a building's } \\
\text { infrastructure and designed to biofilter indoor air and provide thermal regulation (GRHC, } \\
\text { 2008). }\end{array}$ \\
\hline & & $\begin{array}{l}\text { Landscape wall These walls are an evolution of landscape 'berms' and a strategic tool in an } \\
\text { approach to 'living' architecture (GRHC, 2008). }\end{array}$ \\
\hline & \multirow{3}{*}{$\begin{array}{l}\text { Living Walls } \\
\text { According to } \\
\text { Substrate } \\
\text { Material }\end{array}$} & $\begin{array}{l}\text { Potted plant system } \\
\text { It can be defined as creating vertical gardens with panels or pots placed in such plants (Figure } \\
\text { 3). }\end{array}$ \\
\hline & & $\begin{array}{l}\text { Foam-based system In this system, the foam-based substrate which is made of aminoplast } \\
\text { resin foam is mounted to the above carrier profile. This medium which hosts plants is highly } \\
\text { water-efficient and robust for a wide range of plants and climate types (Mir, 2011). }\end{array}$ \\
\hline & & $\begin{array}{l}\text { Felt layer-based system Felt material provides a base for plants such as soil. It allows water to } \\
\text { diffuse homogeneously, and it does not mold. Generally, nutrients and water are carried to the } \\
\text { plants by using a drip irrigation system in this type of vertical garden (Örnek, 2011). }\end{array}$ \\
\hline & & $\begin{array}{l}\text { Mineral wool-based system In this system, the panels which include mineral wool are } \\
\text { mounted above to the carrier profile (Mir, 2011). }\end{array}$ \\
\hline
\end{tabular}




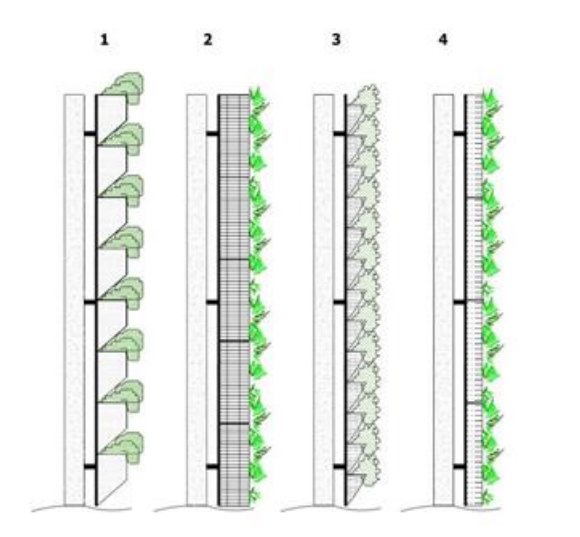

Figure 2 Green facade types (Ottele, 2011)

\subsubsection{Vegetation Wall}

Vegetation wall is a special type of vertical green that usually grows on surface walls and especially in joints or cracks. Self-growth of plants is a natural process. Vegetation wall can be divided into two categories (Mir, 2011) (Photo 2, 3) (Table 5).

Table 5 Wall vegetation classification

\begin{tabular}{l|l}
\hline \multirow{4}{*}{$\begin{array}{c}\text { Wall } \\
\text { Vegetation }\end{array}$} & $\begin{array}{l}\text { Natural Vegetation } \\
\text { These are walls formed by the spontaneous growth of plants at the buildings (Figure 4). }\end{array}$ \\
\cline { 2 - 3 } & $\begin{array}{l}\text { Wall Panel Application Suitable for Vegetation } \\
\text { Concrete panels with a wide variety of pores are new applications developed to create green buildings in a } \\
\text { short time (1-2 years). These panels are also types of facade designed in accordance with the vegetation on } \\
\text { them (Ottele, 2011) (Figure 5). }\end{array}$ \\
\hline
\end{tabular}

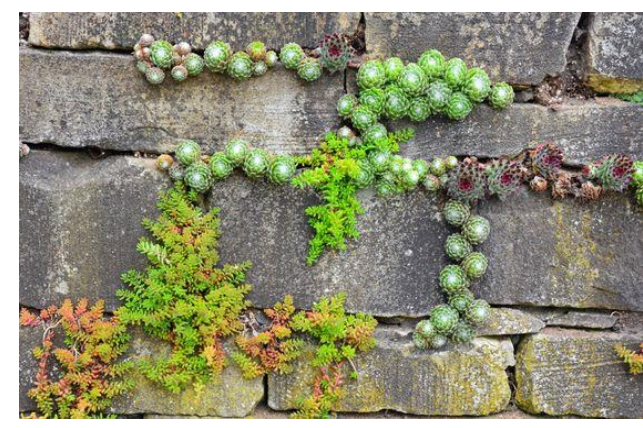

Photo 2 Self-vegetating wall example (URL-4)

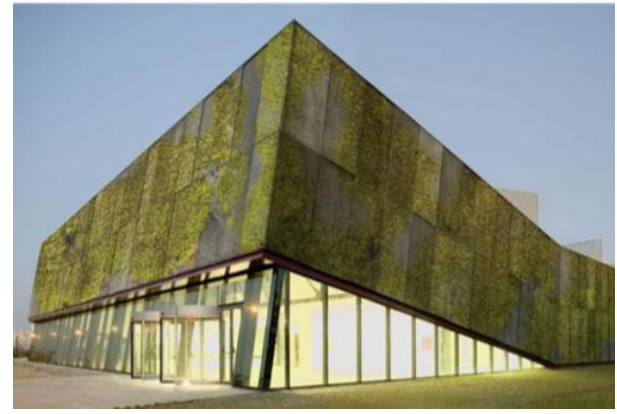

Photo 3 An example of wall panel application suitable for vegetation (URL-5)

\subsubsection{According to Location of Application}

Green walls will be examined in two groups as indoor vertical green systems and outdoor vertical green systems according to the place of application of the vertical green system (Photo 4, 5) (Table 6).

Table 6 Vertical green system classification according to place of application

\begin{tabular}{c|l}
\hline \multirow{2}{*}{\begin{tabular}{c} 
According to $\begin{array}{c}\text { Place of } \\
\text { Application }\end{array}$ \\
\cline { 2 - 2 }
\end{tabular}} & $\begin{array}{l}\text { Indoor Vertical Green Systems } \\
\text { Vertical vegetation is used for decorative purposes in homes and offices, public buildings, shops and restaurants. } \\
\text { Indoor plants filter pollutants from the air, produce oxygen, and even reduce electronic pollution (electrosmog) }\end{array}$ \\
\cline { 2 - 2 } & $\begin{array}{l}\text { Outdoor Vertical Green Systems } \\
\text { Outdoor green systems can be used for functions such as guides, shades, and curtains hiding visible installations } \\
\text { and mechanical systems of buildings (Figure 7). }\end{array}$ \\
\hline
\end{tabular}




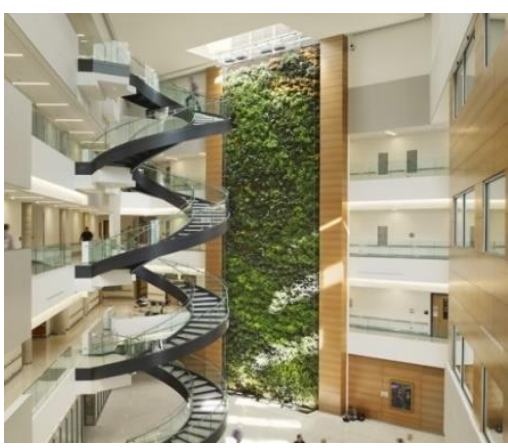

Photo 4 Indoor vertical green system example (URL-6)

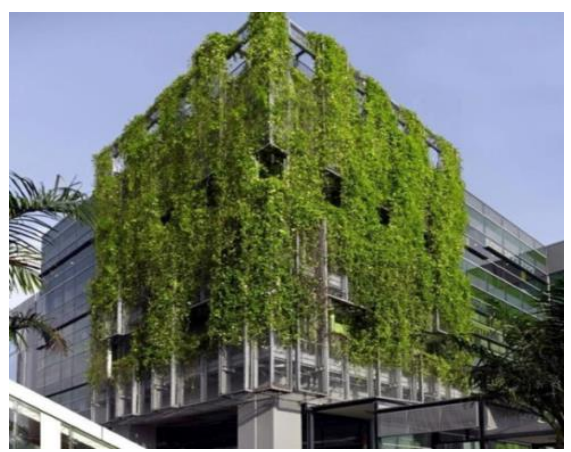

Photo 5 Outdoor vertical green system example (URL-7)

\subsubsection{According to Structural Features}

This classification of vertical green systems is examined under two headings as free and integrated vertical green systems (Photo 6, 7), (Table 7).

Table 7 Vertical green system classification according to its structural design

\begin{tabular}{c|l}
\hline \multirow{2}{*}{$\begin{array}{c}\text { According to } \\
\text { its Structural } \\
\text { Design }\end{array}$} & $\begin{array}{l}\text { Free Vertical Green Systems } \\
\text { Such systems can be located in front of a building or around it without any connection system, and they can also } \\
\text { be individually used as restraining, directing, shading elements by which only plants can be carried and displayed } \\
\text { vertically (Figure 8). }\end{array}$ \\
\cline { 2 - 3 } & $\begin{array}{l}\text { Integrated Vertical Green Systems } \\
\text { Although they are referred to as green facades in the literature, modular trellis panel, cable and wire-rope net } \\
\text { do not necessarily have to be integrated systems. Such applications can also function independently from } \\
\text { building walls (Figure 9). }\end{array}$ \\
\hline
\end{tabular}

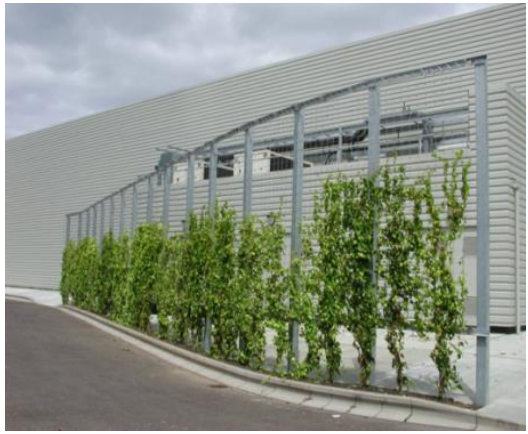

Photo 6 Free vertical green system application example (URL-8)

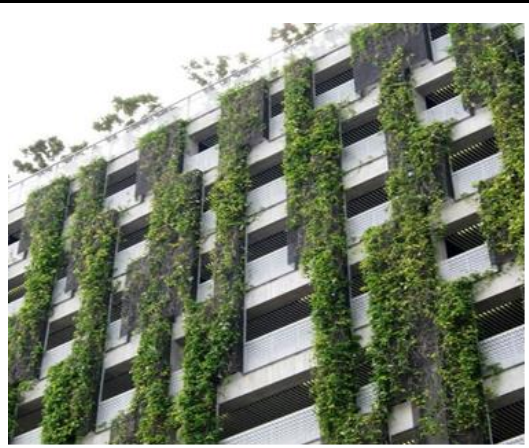

Photo 7 Integrated vertical green system application example (URL-9)

\subsubsection{According to Plant Type}

Vertical green systems according to plant type are examined under two headings as shrub type and climbing-twining plant types (Photo 8, 9) (Table 8).

Table 8 Vertical green system classification according to plant type

\begin{tabular}{c|l}
\hline \multirow{4}{*}{$\begin{array}{c}\text { According to } \\
\text { Plant } \\
\text { Type }\end{array}$} & $\begin{array}{l}\text { Systems Using Shrub Type Plants } \\
\text { These species are not climbers, but by attaching wide mesh grids to the wall, they can be made to gain twining } \\
\text { feature. Soil nutritional value should be high in applications (MEGEP, 2016). Shrub type plants are plants that } \\
\text { are not suitable for green facade applications, but are frequently used for living wall systems (Figure 10). }\end{array}$ \\
\cline { 2 - 3 } & $\begin{array}{l}\text { Systems Using Climbing Plants } \\
\text { For green facade applications, mostly climbing-twining plants are preferred (Khabbazi, Erdoğan, 2013) (Figure } \\
\text { 11). Plant modules are fixed to the wall with screws without requiring construction on the application surface. } \\
\text { It is an easily assembled system with its complementary structure and lightness (Khabbazi, Erdoğan, 2013). }\end{array}$ \\
\hline
\end{tabular}




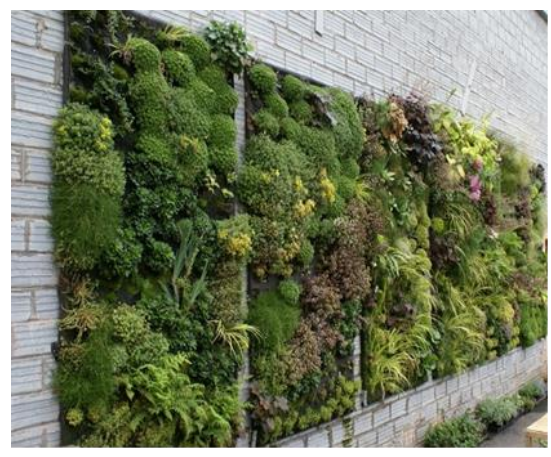

Photo 8 Vertical green system example using shrub plant type (URL-10)

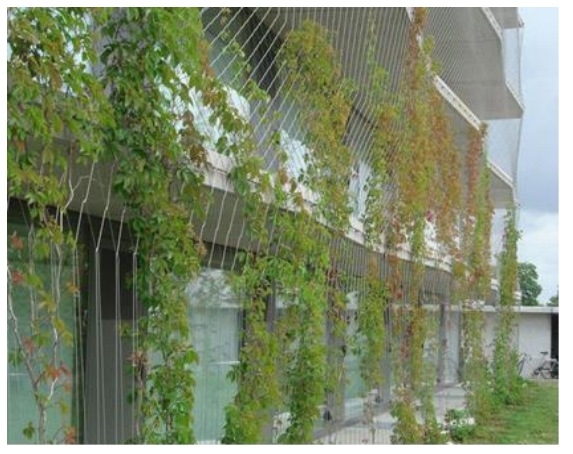

Photo 9 Green facade example using climbing plant (URL-11)

\subsection{Benefits of Vertical Green Systems and Their Evaluation in Ecological Context}

The ecological benefits of vertical green systems; Using water efficiently, cleaning the air, protecting the facade against external factors, acting as shading and insulation and reducing the heating-cooling load can be examined at the building and city scale under the headings. When evaluated at the city scale, the benefits of vertical green systems such as reducing the urban heat island effect, increase in biodiversity and reduction in carbon footprint can be mentioned (Table 9). In this context, the ecological benefits of vertical green systems are examined under common headings for both scales below.

Table 9 Benefits of vertical green systems (Papadopoulou, 2013)

\begin{tabular}{|c|c|c|c|c|}
\hline & Energy & Environment & Economic & Social \\
\hline \multirow[t]{3}{*}{ 占 } & $\begin{array}{l}\text { High building } \\
\text { energy } \\
\text { performance }\end{array}$ & $\begin{array}{c}\text { Efficient water use } \\
\text { through storm } \\
\text { water collection, } \\
\text { water recycling }\end{array}$ & $\begin{array}{l}\text { Less needs for } \\
\text { envelope } \\
\text { maintenance, } \\
\text { protection from UV } \\
\text { damage and } \\
\text { general } \\
\text { deterioration }\end{array}$ & $\begin{array}{l}\text { Improvement in } \\
\text { residents' wellbeing } \\
\text { through better } \\
\text { indoor air quality }\end{array}$ \\
\hline & $\begin{array}{l}\text { Act as insulation } \\
\text { material, heat loss } \\
\text { management }\end{array}$ & \multirow[t]{2}{*}{$\begin{array}{l}\text { Air purification } \\
\text { and dust } \\
\text { suppression }\end{array}$} & $\begin{array}{l}\text { Increase of } \\
\text { property/resale } \\
\text { value, as it is } \\
\text { considered design } \\
\text { trend }\end{array}$ & \multirow[t]{2}{*}{$\begin{array}{l}\text { Fulfillment of the } \\
\text { EU sustainable } \\
\text { targets }\end{array}$} \\
\hline & $\begin{array}{l}\text { Act as shading } \\
\text { device, regulating } \\
\text { internal } \\
\text { temperatures }\end{array}$ & & $\begin{array}{c}\text { Earn additional } \\
\text { points in LEED* } \\
\text { credit system }\end{array}$ & \\
\hline \multirow{3}{*}{ تِ } & \multirow{3}{*}{$\begin{array}{l}\text { Natural air-cooling } \\
\text { around the } \\
\text { building }\end{array}$} & UHI mitigation & Local job creation & $\begin{array}{c}\text { Reduction of urban } \\
\text { noise pollution }\end{array}$ \\
\hline & & $\begin{array}{l}\text { Reduced carbon } \\
\text { footprint }\end{array}$ & $\begin{array}{l}\text { Increase } \\
\text { neighboring real } \\
\text { estate value by up } \\
\text { to } 20 \%\end{array}$ & $\begin{array}{l}\text { Improvements in } \\
\text { health and } \\
\text { wellbeing of the } \\
\text { society }\end{array}$ \\
\hline & & $\begin{array}{l}\text { Air-pollution } \\
\text { mitigation }\end{array}$ & $\begin{array}{l}\text { Increase urban } \\
\text { agriculture }\end{array}$ & $\begin{array}{l}\text { Improve city } \\
\text { aesthetics } \\
\text { Behavioral } \\
\text { improvements: less } \\
\text { violence, crime } \\
\text { reduction }\end{array}$ \\
\hline
\end{tabular}




\subsubsection{Energy Saving}

During summer, sun radiation heats the building envelope, leading to an increased demand for cooling and energy requirements. Green walls can reduce indoor temperatures due to shading provided by the plants, resulting in decreased indoor cooling needs and costs (URL-12). These effects vary according to climatic characteristics. The energy efficiency of vertical green systems has been examined separately in terms of hot-humid climate and hot-dry climate properties.

\subsubsection{Hot and humid climate}

The climatic indicator of a hot and humid climate is excessive heat and humidity. The purpose of using ideal green walls in this climate is therefore to reduce the thermal load while avoiding an increase in humidity. According to Chen, using living wall systems reduces the indoor temperature by a maximum of $1.1 \circ \mathrm{C}$, while the mean indoor temperature is $0.4 \circ \mathrm{C}$ less than spaces without LWS (Living Wall System). A common concern about the factor of humidity is that the LWS may increase relative humidity due to its humid bed as well as the plants sweating. The relative humidity of the air layer is higher than that in the environment during the day and lower at night (Chen, Li, Liu, 2013). The LWS creates therefore more stable relative humidity in the air layer near the wall surface without increasing the indoor relative humidity. The results indicate that the LWS has a high cooling effect on the wall surface and indoor space, and the exterior wall surface gives off heat to the environment instead of receiving heat.

An important effect of living walls is shadowing, which greatly affects the cooling period. The shadow effect also causes a temperature reduction and a radiation reduction, and also a proper design of the green cover can result in significant energy saving. The temperature fluctuations in the LWS with still air follows the temperature fluctuation rhythm of outdoor temperature in smaller intervals such that the wall temperature is less than the outdoor maximum temperature by about $5^{\circ} \mathrm{C}$. While the layer investigated in living walls with still air chambers follows the air temperature fluctuations and does not exceed the hottest outdoor temperature, the layer investigated in living walls with ventilated air chambers reveals a temperature difference of about $10^{\circ} \mathrm{C}$ compared to outdoor, it is hotter on average by $10^{\circ} \mathrm{C}$ (Zarandi and Pourmousa, 2018).

\subsubsection{Hot and dry climate}

Excessive heat and very low air humidity are the two most significant climatic indicators in hot and dry climates. So, all efforts will therefore be made to control these two factors. Many studies confirm the thermal effects of vertical green surfaces on the building envelope. There is credible evidence indicating that vertical green systems can reduce the air conditioning load by shadowing walls and windows, reducing the temperature, and a significant amount of annual savings can be considered. Results of investigations indicate that green facades in hot and dry climates can maintain a temperature which is lower than that of a simple wall at the peak daily heat of summer. This affects the building cooling load and improves the energy performance. According to Alexandri et al. (2008), using plants is more effective on the urban temperature in hotter and drier climates. Saving in energy consumption for the cooling of buildings will be $23 \%-100 \%$. The reasons why living walls cause temperature reductions are summarized as follows:

- Reducing heat absorption caused by the plants

- Evaporative cooling caused by irrigation

- Heat resistance due to low thermal conductivity (Haggag, Hassan, Elmasry, 2014) 


\subsubsection{Air Quality}

Elevated temperatures in modern urban environments with increasing numbers of vehicles, air conditioners and industrial emissions have led to a rise in nitrogen oxides, sculpture oxides, volatile organic compounds, carbon monoxide and particulate matter. Green facades or Green Walls can capture airborne pollutants and atmospheric deposition on leaf surfaces. And it can filter noxious gases and particulate matter. A study shows that Approximately 1 square foot of vegetated wall area will filter the air for approximately 100 square feet of office area. Considered in a very general sense, planting one wall of any 50 buildings which are situated on the street is equal to planting 50 trees on this street (Elgizawy Ebtesam, 2016). For interior projects, green walls are able to filter contaminants that are regularly flushed out of buildings through traditional ventilation systems. The filtration is performed by plants, and in the case of bio-filtration, micro- organisms. Green facade can capture airborne pollutants such as dust and pollen. And it filters noxious gases and volatile organic compounds foam carpets, furniture and other building elements (Elgizawy Ebtesam, 2016).

\subsubsection{Conserves Water}

One of the biggest impacts of Green facade is how they manage water. For starters, watering is very efficient as it is done using a drip irrigation system or a hydroponic system. Any waste water is collected at the bottom of the garden in a special tray where it is drained away. Alternatively, it can be recycled and put back on the garden (Figure 3 ). This means that practically all the water is used up by the plants, and there is very little waste (Elgizawy Ebtesam M., 2016).

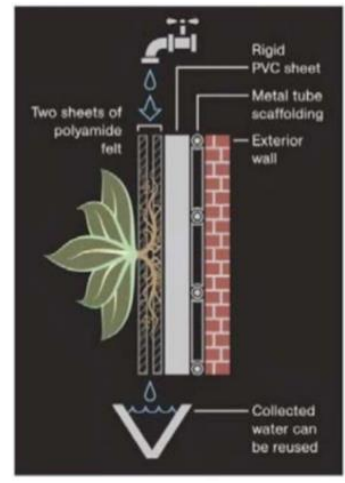

Figure 3 Schematic representation of rainwater management (Elgizawy Ebtesam, 2016)

\subsubsection{Noise Reduction}

Green facades have a noise absorption feature with their soil and plants which are used for planting. For this reason, they have a function of decreasing the noise occurring both in the building and its immediate surroundings. Green Walls provide a noise buffer which significantly reduces outside noise and vibration (up to 40 decibels) inside our homes and workplaces. A small indoor hedge placed around a workspace will reduce noise by 5 decibels (Elgizawy Ebtesam, 2016).

\subsection{Vertical Green Systems in Educational Buildings}

It is seen that the importance of sustainable design has been emphasized in recent studies in which the environmental conditions that schools are required to have are defined. Within the definition of sustainable school, energy and water conservation, minimization of waste, avoidance of potential pollutants, protection and support of natural life, effective use of financial resources, and respect for the participation of people are generally addressed (Murphy and Thorne, 2010). 
There are several criteria for designing, operating and maintaining sustainable educational buildings that provide economic and environmental benefits as well as positively affecting students' health and learning (Frenette et al., 2003). These criteria are:

- Sustainable space planning and landscape design that reduce pesticide use and provide an outdoor learning environment for students.

- Building envelope design with high insulation value with windows positioned to provide air flow and increase the comfort levels of students and teachers.

- Lighting design that improves student performance and increases comfort levels, allowing daylight use at the maximum level.

- Ensuring good indoor air quality obtained from adequate air filtration and exchange systems, and introducing prohibitions that eliminate toxins, allergens and other sources of harmful pollutants. For example; prohibition of buses or distribution trucks operating near buildings.

- Design and maintenance of heating, cooling and ventilation systems that work silently and efficiently and do not distract students from learning by causing noise.

- Use of renewable energy sources on site such as photovoltaic that can be used as a teaching tool to increase students' interest in alternative energy sources.

An important development in education in the years between 1930-1945 was the introduction and development of the concept of student-centered learning, which is still present today. The student-centered learning method developed was first applied in Cranbrook Boys' High School and Tehtaanmaki School as an "outdoor school" movement (Baker, 2012).

Educational buildings in the outdoor school layout stand out with their bright, open-air learning and easy circulation facilities. The importance of clean air, which leads to physical health and wellbeing in mentally based activities, is emphasized in outdoor schools with a functional understanding. The best example of this is seen in the adult learning center at Impington College (Figure 4). In the 1930s, the importance and psychology of the student-centered system in the standardization of educational structures and open-plan school design were emphasized. Interior environmental quality standards were roughly determined but remained in the background due to economic problems. In the years between 1960-1980, educational researchers defined the connections between school facilities and their impact on students' learning for the first time (Baker, 2012).

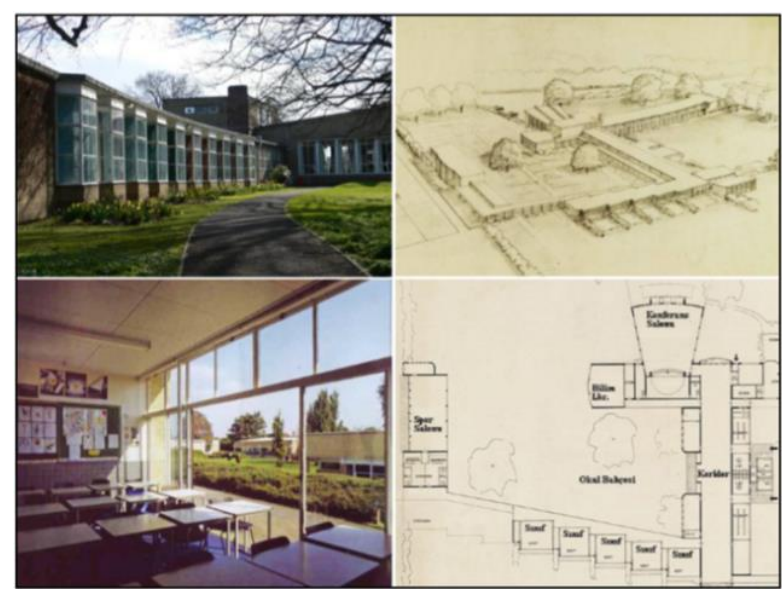

Figure 4 Outdoor school example - Impington School (Baker, 2012)

The major development in the 1990s was the emergence of green building or high performance building concepts (Figure 5). The LEED institute set standards largely for new school design and construction. In the 2000s, interest in high-performance educational buildings gradually increased. 
In order to investigate the reliability of LEED certified buildings and to emphasize the green building concept, states started to measure performance (Baker, 2012).

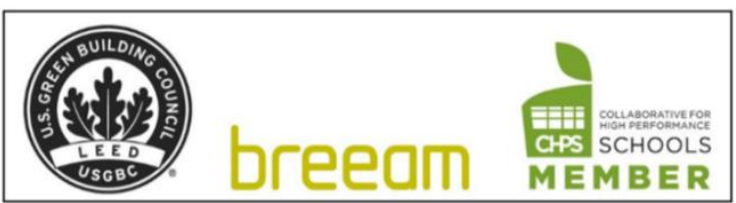

Figure 5 Green Building Rating Agencies

Industrial organizations have researched the basic needs of the heating, ventilation and air quality of classrooms, and took some decisions regarding the realization of mental activities such as

- Humidity of the classrooms being between $40-70 \%$,

- Temperatures being around 68-75 F ( $\approx 20-24 \mathrm{C})$,

- Maintaining 1,000 ppm and 1,500 ppm levels in order to keep CO2 levels low.

As a result of the increase in asthma cases in educational buildings, research on air pollutant particles and their effects was carried out by ASHRAE in 1990. ASHRAE, linking open air supply and indoor air quality with student performance, accepted ventilation rate per person as $10 \mathrm{cfm}$ (minimum) (Baker, 2012).

With such importance attributed to air quality, the vertical green system concept has gained importance for educational buildings. The annex building of the Drew School in America, built in 2011, is one of the first LEED gold-certified schools with its 160-square-meter living wall system (Photo 10).

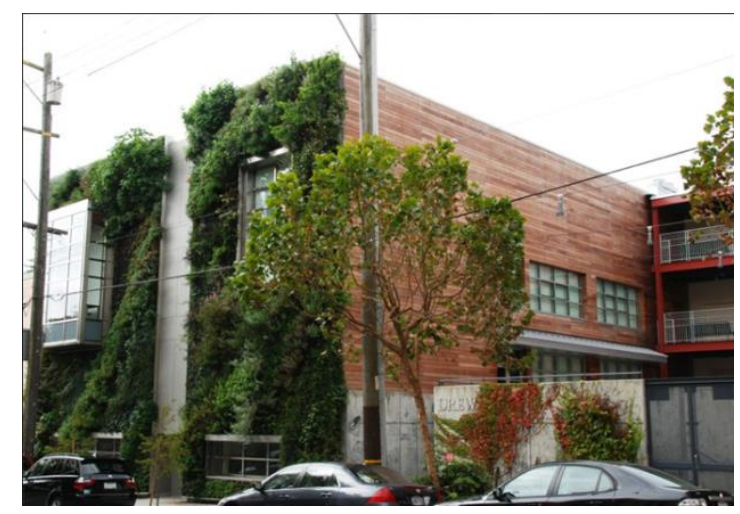

Photo 10 LEED Gold-Certified School Drew School-California (URL -13)

The benefits provided by vertical green systems are:

- Providing the acoustic comfort required for lectures with its noise absorbing effect,

- Providing indoor air quality by absorbing harmful gases and keeping the oxygen balance at a sufficient level,

- Supporting the thermal comfort of the training structure by providing energy efficiency,

- Providing positive effects on student psychology by integrating green and plant into the classroom environment,

- Providing students with a space that they can use as an educational space to study different plant and insect species (Photo 11, 12). 
When we examine the examples, the systems that we see applications on educational buildings after the 2000s have also been taken as criteria by the green building rating agencies mentioned above.

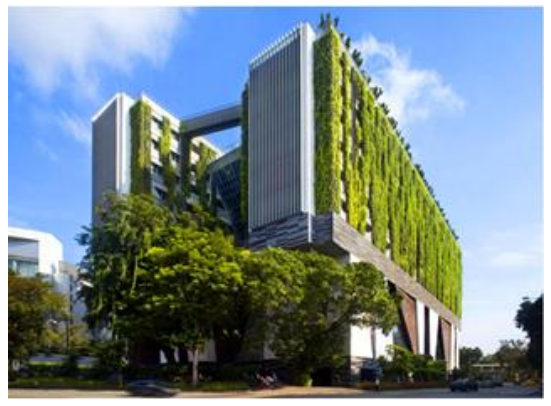

Photo 11 Green facade - Educational building example with wire mesh net system application (URL -14)

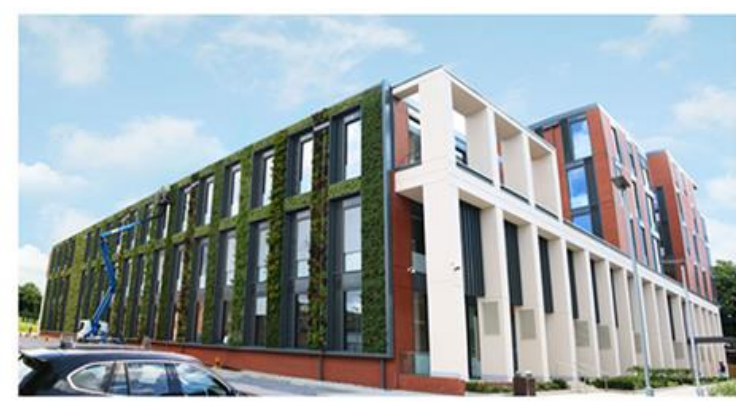

Photo 12 Living wall - educational building example with modular system application (URL -15)

\subsection{An Experimental Study on Th Energy Performance and Evaluation of Vertical Green Systems}

Adana, where the educational buildings in the study are located, is located in the Mediterranean region between $36^{\circ} 30-38^{\circ} 25$ north latitudes and $34^{\circ} 48-36^{\circ} 41$ east longitudes located in the south of the Anatolian peninsula and on the Mediterranean coast (Figure 6). Adana-Çukurova region is in hot-humid climate zone. The region has Mediterranean climate characteristics; summers are very hot and dry, winters are warm and rainy.

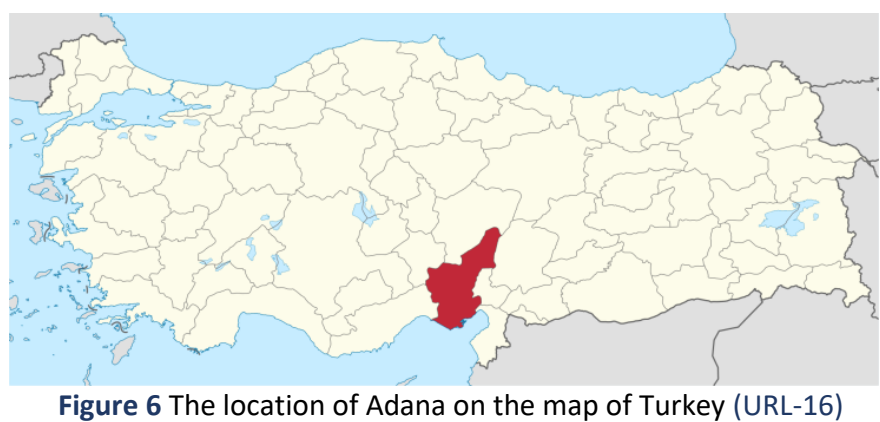

Çukurova University, one of the two universities in Adana province, is located around the dam lake and has a large campus with a dense green area. In the application phase of the energy analysis of vertical green systems of the study, it was planned to make a comparative analysis on these structures by choosing from the educational buildings in the campus area of Çukurova University (Photo 13).

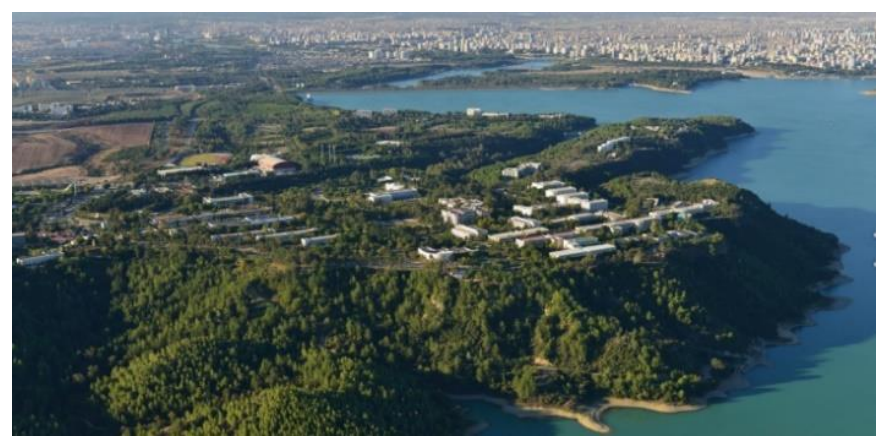

Photo 13 Çukurova University campus view (URL-17) 
These stages are listed below:

- $\quad$ Determining current educational buildings to be implemented

- Creating models and introducing parameters to Revit

- Calculation of heating and cooling loads for modeled structures

- Calculation of the total energy loads of the modeled structures

- Comparison of calculated energy loads

\subsubsection{Determining the Models to be Applied in the Study}

Since the benefits of vertical green systems according to their facade directions were also intended to be compared in the study, two educational buildings with similar facade proportions but differently positioned were selected, and the buildings were modeled in the Revit program (Figure $7,8,9,10$ ). The first analysis was made with the assumption that a vertical green system was applied to the north and south facades of the Faculty of Economics and Administrative Sciences Block $A$ building where the surface area was large and the active areas of use were dense, and energy efficiency tables were created (Table 10).

Table 10 Faculty of Economics and Administrative Sciences Block A building project summary

\begin{tabular}{ll}
\hline \hline Location Information & \\
\hline \hline Project & Faculty of Economics \\
\hline \hline Address & Adana \\
\hline \hline Calculation date and time & 18 September 2020, Friday, 19:58 \\
\hline Latitude & $37.06^{\circ}$ \\
\hline Longitude & $35.35^{\circ}$ \\
\hline \hline
\end{tabular}

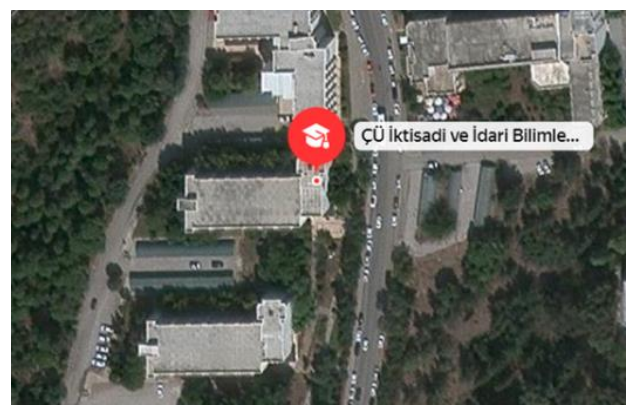

Figure 7 Map view of the Block $A$ building of the Faculty of Economics and Administrative Sciences

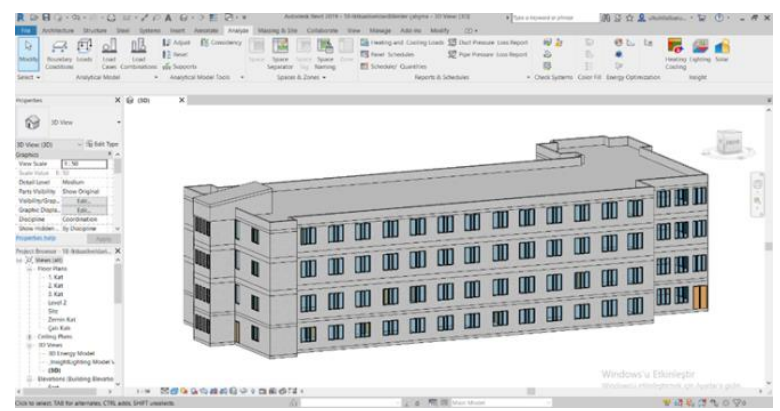

Figure 8 The Revit model of the current situation of the Block A building of the Faculty of Economics and Administrative Sciences

For the second analysis, the R2 classrooms building with an east-west facade, where the surface area was large and the active use areas were dense, was selected. On the assumption that a vertical green system was applied along the facades in the east-west direction, an energy efficiency table was created (Table 11).

Table 11 R2 classrooms building project summary

\begin{tabular}{ll}
\hline Location Information & \\
\hline \hline Project & R2 Classrooms \\
\hline \hline Address & Adana \\
\hline \hline Calculation date and time & 11 October 2020, Sunday, 23:41 \\
\hline \hline Latitude & $37.06^{\circ}$ \\
\hline \hline Longitude & $35.35^{\circ}$ \\
\hline \hline
\end{tabular}




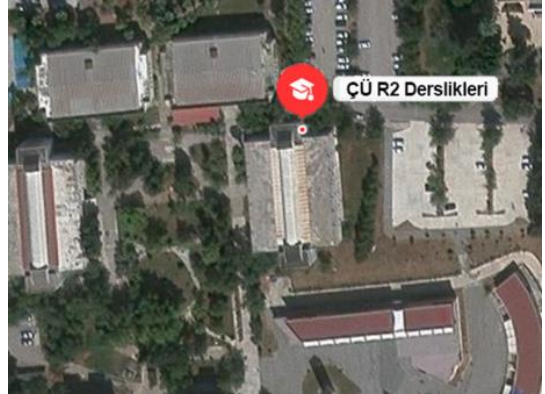

Figure 9 Map view of the R2 building

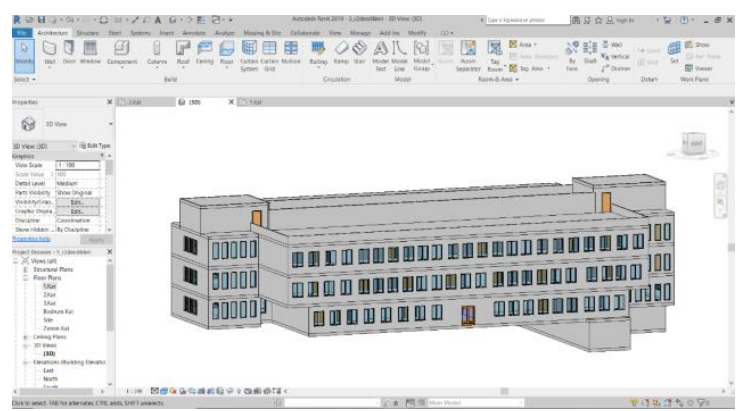

Figure 10 The Revit model of the current situation of the R2 building

\subsubsection{Determination of the Vertical Green System to be implemented}

Among the vertical green systems used in the study, modular living wall systems were applied to the north and south facades of one building and to the east and west facades of the other building. The reason why modular living walls were chosen was that there was artificially arranged vegetation on the vertical surfaces of the building and the planting environment within the module. Modules can be supplied and changed regularly when an addition is intended to be made. The use of felt as the substrate material for the planting medium also provides ease of maintenance in terms of the fact that the felt is not affected by water and therefore does not decay (Figure 11, 12). This situation also extends the life of the plant.

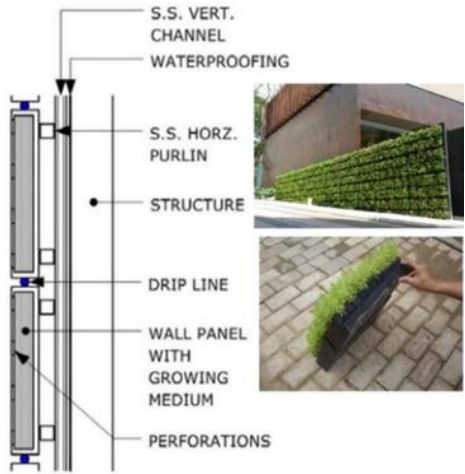

Figure 11 Vertical Green System Type selected for Analysis (Papadopoulou G.,2013)

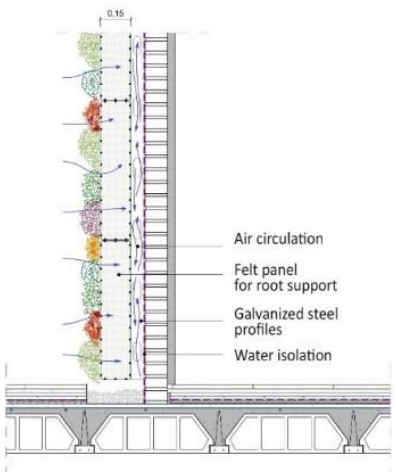

Figure 12 Modular Living Wall Detailed Drawing (URL 18)

4.6.3. Introduction of Parameters to the Program and the Results of the Energy Analyses Performed

In the vertical green system design to be applied, the most important issue that should be considered after the climatic characteristics of the region is the facade characteristics of the building. It is important to know the parameters of the façade and to design accordingly in order to make a design suitable for the climate in the vertical green system to be applied. In this context, the educational buildings selected from the Çukurova University campus has been taken and modeled in the revit program. The living wall system which is thought to be the most suitable for the working area has been applied on the existing reinforced concrete wall, and the necessary parameters have been entered into the program. For modeling, necessary parameters such as occupancy rate on the façade, wall layers and material information have been loaded into the program and the data was tried to be explained in detail under this heading (Figure 13). 


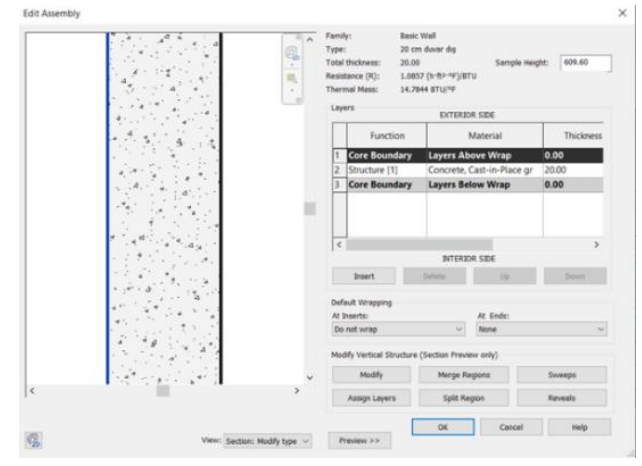

Figure 13 Reinforced concrete exterior wall defined for the existing building in the Revit program

Using the detailed drawings and photographs of the modular living wall system to be applied, the layers of the vertical green wall system were determined. The waterproofing layer placed on the reinforced concrete wall layer is initially positioned under the plant growth environment and protects the wall from the harmful effects of the moist environment. Later, the air gap between the plant support elements and insulation layer was added between the wall layers. Then, the felt layer on which the plant will be rooted on the steel support elements and the plant layer on it were entered into the program (Figure 14).

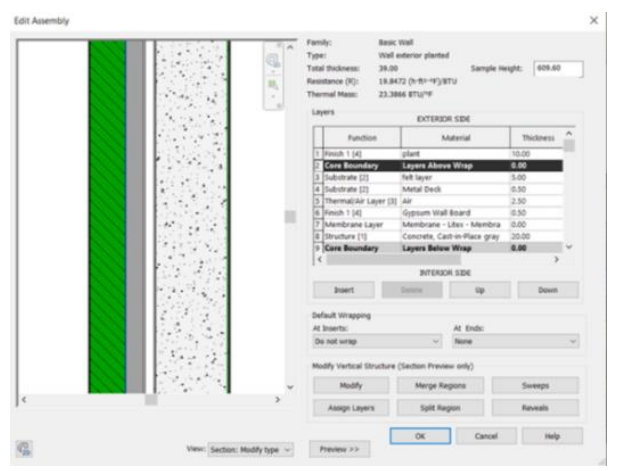

Figure 14 Living wall defined for the building with vertical green system in the Revit program

Energy analysis software can simulate the vegetation layer on the green facade as a kind of "insulation material" that is attached to the wall in the same way by adjusting the vegetation height, leaf area index, leaf reflection rate, leaf emission and minimum stoma resistance of the greening layer (Pan, Xiao, 2014). With this information, a new material was added for the plant layer, the thermal value of which we set (Figure 15). The thermal values of this new material were obtained from the article of Pan and Xiao. Equivalents of the parameter in the simulation, the absorbency coefficient of the green layer was 0.8 ; the density of the green layer was $300 \mathrm{~kg} / \mathrm{m} 3$; and the thermal conductivity of the green layer $(\lambda)$ was $0.15 \mathrm{~W} / \mathrm{m} \bullet \mathrm{k}$ (Pan, Xiao, 2014).

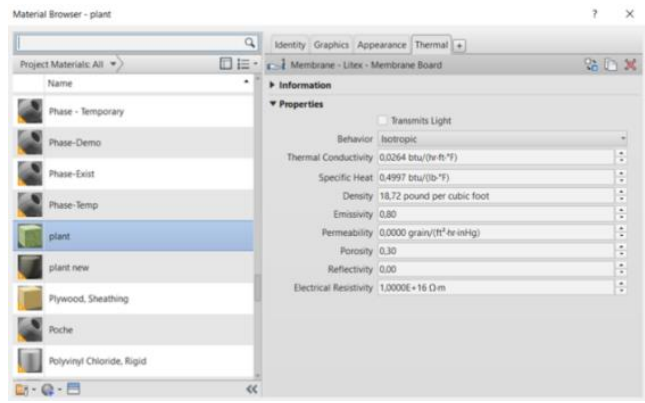

Figure 15 Living wall vegetation layer thermal values defined for the building with vertical green system in the Revit program 
The plant layer was formed by converting these values according to the unit system of the program.

- Emissivity (Absorption coefficient)

- The Density Unit was taken as pound per cubic foot.

- The Thermal Conductivity Unit was taken as Btu/h er.ft.F.

The living walls were installed along the north and south facades of the Faculty of Economics and Administrative Sciences Block A building on the side where the classroom and administration areas are located (Figure 16, 17).

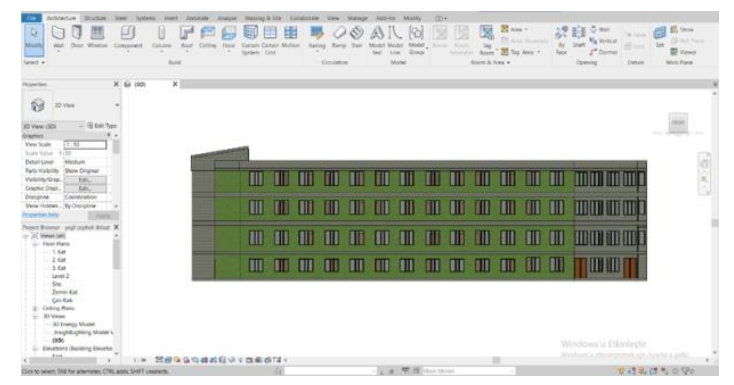

Figure 16 Faculty of Economics and Administrative Sciences Block A Building South Facade View with Vertical Green System Applied

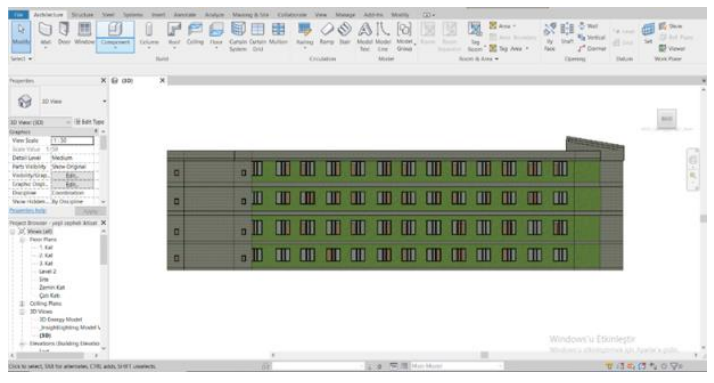

Figure 17 Faculty of Economics and Administrative Sciences Block A Building North Facade View with Vertical Green System Applied

The living walls were installed along the east and west facades of the $\mathrm{R} 2$ classrooms building on the side where the classroom and administration areas are located (Figure 18, 19).

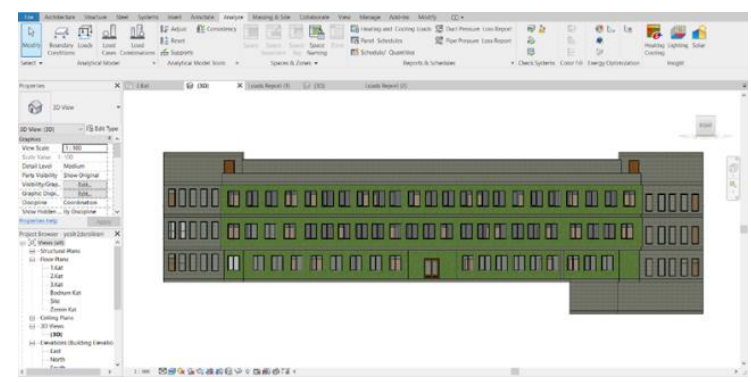

Figure 18 R2 Classrooms building west facade view with vertical green system applied

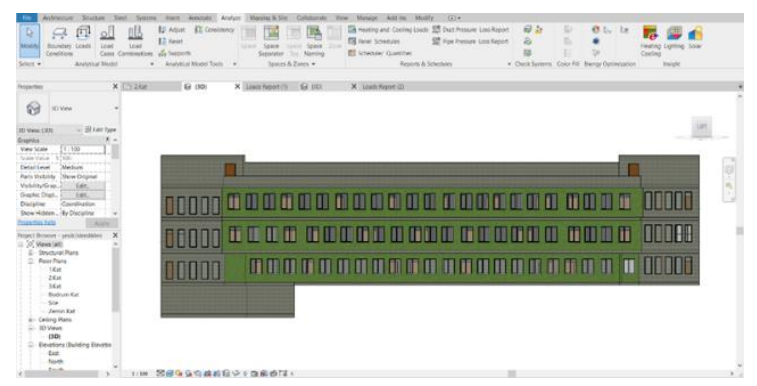

Figure 19 R2 Classrooms building eastern facade view with vertical green system applied

Location information of the project was entered. Then, heating-cooling loads were calculated over Revit, and tables were formed (Figure 20).

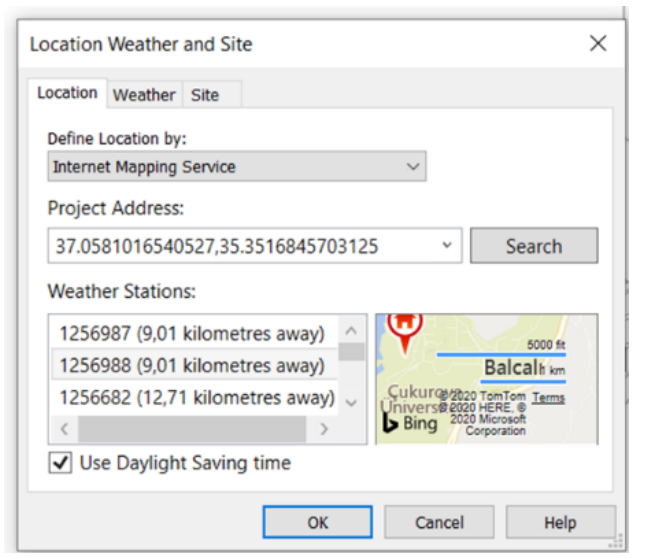

Figure 20 Defining location information in Revit program 


\subsubsection{Calculation of Heating Cooling Load}

After entering the necessary parameters (type of building, weekly active usage time, thermal values of wall layers, location information of the building, etc.) to calculate the heating and cooling load, energy simulation was performed through the Revit program. The obtained heating-cooling load analysis charts are as follows (Tables 12, 13).

Table 12 Heating, cooling load analysis comparison table of the Faculty of Economics and Administrative Sciences, Block A building

\begin{tabular}{|c|c|c|}
\hline Data & Current Situation & $\begin{array}{l}\text { Situation with vertical } \\
\text { green system applied }\end{array}$ \\
\hline Building Type & University & University \\
\hline Area $\left(m^{2}\right)$ & 3,648 & 3,648 \\
\hline Volume $\left(\mathrm{m}^{3}\right)$ & $10,597.60$ & $10,597.60$ \\
\hline \multicolumn{3}{|l|}{ Results } \\
\hline Total Cooling Load (Btu/h ) & $1,842,839.8$ & $1,534,215.0$ \\
\hline Month and Hour with the highest cooling load & September 16:00 & September 14:00 \\
\hline Maximum Cooling Capacity (Btu/h ) & $1,640,583.0$ & $1,303,107.7$ \\
\hline Total Heating Load (Btu/h ) & $1,365,406.5$ & $1,107,296.3$ \\
\hline \multicolumn{3}{|l|}{ Inputs } \\
\hline Cooling point & $74^{\circ} \mathrm{F}$ & $74^{\circ} \mathrm{F}$ \\
\hline Heating point & $70^{\circ} \mathrm{F}$ & $70^{\circ} \mathrm{F}$ \\
\hline Temperature Value & $54^{\circ} \mathrm{F}$ & $54^{\circ} \mathrm{F}$ \\
\hline Number of people & 913 & 913 \\
\hline Relative humidity & $38.00 \%$ (calculated) & $42.00 \%$ (Calculated) \\
\hline \multicolumn{3}{|l|}{ Checksums } \\
\hline Cooling Load Density $\left(\right.$ Btu / $\left.\left(\mathrm{h} \cdot \mathrm{ft}^{2}\right)\right)$ & 41.78 & 33.30 \\
\hline Cooling Flow Density (CFM / SF) & 1.69 & 1.61 \\
\hline Cooling Flow / Load (CFM / ton) & 485.36 & 581.29 \\
\hline Cooling Area / Load (SF / ton) & 287.23 & 360.36 \\
\hline Heating Load Density $\left(B t u /\left(h \cdot \mathrm{ft}^{2}\right)\right)$ & 34.77 & 24.80 \\
\hline
\end{tabular}

According to the results of the table data above, when the total heating and cooling loads of the Faculty of Economics and Administrative Sciences Building A were examined, the total current cooling load was approximately $1,842 \mathrm{Btu} / \mathrm{h}$, while it was measured to be approximately 1,534 $\mathrm{Btu} / \mathrm{h}$ as a result of vertical green system application. This means a reduction in cooling load by about $17 \%$. The heating load was measured at $1,365 \mathrm{Btu} / \mathrm{h}$ in current situation. When the vertical green system was applied, it was measured to be approximately 1,107 Btu/h. This means a reduction in the heating load by $19 \%$. Although the cooling-heating load decreased, the analysis results also showed that the relative humidity increased. Relative humidity increased by $4 \%$ due to the thermal values of the plant. A certain decrease in cooling-heating load and flow densities was determined (Table 12).

Table 13 R2 classrooms building heating-cooling load analysis comparison chart

\begin{tabular}{l|l|l}
\hline Data & Current Situation & $\begin{array}{l}\text { Situation with vertical } \\
\text { green system applied }\end{array}$ \\
\hline Building Type & University & University \\
\hline Area $\left(\mathrm{m}^{2}\right)$ & 3,868 & 3,868 \\
\hline Volume $\left(\mathrm{m}^{3}\right)$ & $11,542.83$ & $11,542.83$ \\
\hline Results & & \\
\hline Total Cooling Load (Btu/h ) & $\mathbf{2 , 2 1 0 , 3 6 5 . 5}$ & $\mathbf{1 , 8 6 2 , 7 4 2 . 8}$ \\
\hline Month and Hour with the highest cooling load & August $14: 00$ & August $14: 00$ \\
\hline Maximum Cooling Capacity (Btu/h ) & $2,210,365.5$ & $1,806,742.8$ \\
\hline Total Heating Load (Btu/h ) & $\mathbf{1 , 1 5 1 , 8 3 8 . 8}$ & $\mathbf{9 3 3 , 9 4 4 . 2}$ \\
\hline Inputs & & \\
\hline Cooling point & $74^{\circ} \mathrm{F}$ & $74^{\circ} \mathrm{F}$ \\
\hline Heating point & $70^{\circ} \mathrm{F}$ & $70^{\circ} \mathrm{F}$ \\
\hline Temperature Value & $54^{\circ} \mathrm{F}$ & $54^{\circ} \mathrm{F}$ \\
\hline Number of people & 974 & 974 \\
\hline Relative humidity & $46.00 \%$ (calculated) & $50.00 \%$ (calculated) \\
\hline & &
\end{tabular}




\begin{tabular}{l|l|l}
\hline Checksums & & \\
\hline Cooling Load Density (Btu / (h $\left.\left.\cdot \mathrm{ft}^{2}\right)\right)$ & 52.74 & 43.40 \\
\hline Cooling Flow Density (CFM / SF) & 1.22 & 0.83 \\
\hline Cooling Flow / Load (CFM / ton) & 276.46 & 228.58 \\
\hline Cooling Area / Load (SF / ton) & 227.51 & 276.51 \\
\hline Heating Load Density (Btu / $\left.\left(\mathrm{h} \cdot \mathrm{ft}^{2}\right)\right)$ & 27.49 & 20.25 \\
\hline
\end{tabular}

Considering the total heating and cooling loads according to the results of the table data above, the total cooling load was approximately $2,210 \mathrm{Btu} / \mathrm{h}$ in the current situation, while it was measured to be approximately $1,862 \mathrm{Btu} / \mathrm{h}$ with the vertical green system applied. This means a reduction in cooling load by about $16 \%$. The heating load was measured at $1,151 \mathrm{Btu} / \mathrm{h}$ in the current situation. When the vertical green system was applied, it was measured to be approximately $993 \mathrm{Btu} / \mathrm{h}$. This means a reduction in the heating load by $19 \%$. Results similar to the results of the analysis of the Faculty of Economics and Administrative Sciences Building A were obtained, and it was observed that the relative humidity increased by $4 \%$ in the energy analysis results of the R2 classrooms building. A certain decrease in cooling-heating load and flow densities was also determined (Table 13).
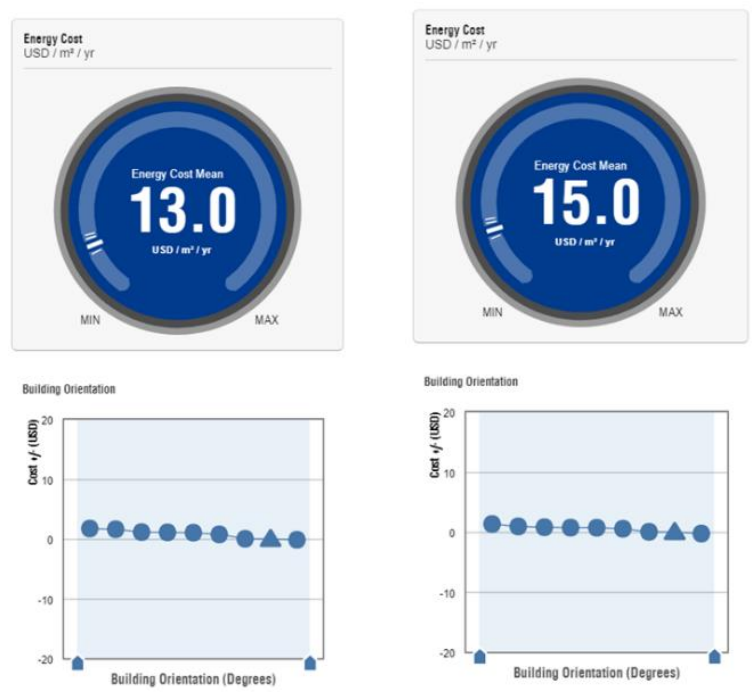

Figure 21 Revit-Insight building energy-cost analysis

In addition to the heating-cooling load analysis, Revit-Insight building energy-cost analysis was performed. While the energy cost for both buildings decreased by $\$ 15$ per square meter per year over the total square meter of the building settlement, it was seen that it decreased to $\$ 13$ per square meter provided that the vertical green system was applied (Figure 21). Therefore, the reduction in the heating and cooling load also decreased the annual energy cost.

As a result of the above energy analyses performed in the study, the following results were reached:

- Vertical green systems could reduce the heating-cooling load by about $16-19 \%$,

- There was an increase by $4-5 \%$ in humidity as a result of perspiration caused by the plant and evaporation of water,

- For the hot-humid climate zone, there was no difference between the north-south axis facades and the east-west axis facades in terms of energy conservation, and

- It reduced the annual energy consumption cost.

Adana-Çukurova region is in a hot-humid climate zone. The results obtained revealed that vertical green systems displayed the same energy performance when applied in a hot-humid climate zone regardless of the facade. The information that vertical green systems applied in the 
hot-humid climate zone have a high cooling effect on the building surface and in the interior, and that the exterior wall surface with vertical green system application gives heat to the environment instead of taking heat was supported by the analysis results. The most important and first reason for this is that the building surface is not directly exposed to sunlight thanks to the plant layer. The second reason is that the water in the system evaporates as a result of watering the plant, cooling the surface by taking heat from the facade surface. But the negative result of the second reason appears as the increase in relative humidity. However, this situation is negligible in consideration of the high cooling effect. In addition, vertical green systems will help reduce the urban heat island effect due to the cooling effect mentioned in hot-humid climates.

\section{Conclusion and Suggestions}

In order not to be deprived of the environmental benefits of sustainable designs and to reveal the responsibilities that the society should undertake for environmental health, it is necessary to create and develop awareness by transferring knowledge from generation to generation through education. The method of teaching through experimenting, which is known to be more effective and permanent in teaching behaviors respecting the nature and the environment than teaching theoretically, should be emphasized in educational buildings. This can only be achieved by designing educational buildings in line with sustainable goals. In this context, vertical green systems are considered as one of the systems that contribute to achieving sustainable design goals in educational buildings due to their being visible and bringing nature and the green to educational environment.

Vertical green systems are solutions whose importance cannot be underestimated in order to develop new and environmentally sensitive understandings in architecture and to create more livable cities. The benefits of properly designed vertical green systems at the urban and building scale will return to us as concrete data rather than being only a concept in the literature. By introducing these solutions to educational buildings, a series of environmental problems that can be foreseen in the future can be prevented. As a result, in the study, classification of vertical green system types, examination of the examples of educational structures in which these systems are applied, and revealing the benefits obtained by simulating the vertical green systems applied in the study in educational structures are expected to support and guide future studies.

\section{References}

AIA - The American Institute of Architects. (2007). Integrated project delivery: A guide. AIA Publications USA, $1,17$.

Alexandri, E. and Jones, P. (2008). Temperature decreases in an urban canyon due to green walls and green roofs in diverse climates. Building and Environment, 43(4), 480-493.

Baker, L. (2012). A History of School Design and its Indoor Environmental Standards 1900 to Today. National Clearinghouse for Educational Facilities, 5-13.

Bjerre, L. A. (2011). Green Walls Via University College. 7 Semester Dissertation Bachelor of Architectural Technology and Construction Management, 9-18.

Brundtland, G.H. (1987). Our Common Future. Report of the World Commission on Environment and Development, 37. [PDF document]. In 15 November 2020 Available from website: https://www.are.admin.ch/are/en/home/sustainable.development/international.cooperation/2030ag enda/un-_-milestones-in-sustainable-development/1987--brundtland-report.html

Chen, Q. Li, B., Liu, X. (2013). An experimental evaluation of the living wall system in hot and humid climate. Energy and Buildings, 61, 298-307.

Curran, M. A. (2000).The international conference \& exhibition on life cycle assessment (InLCA): tools for sustainability. The International Journal of Life Cycle Assessment, 5(3), 160. doi:10.1007/bf02978617

Elgizawy Ebtesam, M. (2016). The Effect of Green Facades in Landscape Ecology. Elsevier Journal, Procedia Environmental Sciences, 34, 125-126. 
Frenette, E. Dion, M. Halm, P. Ferzacca, N. Oldeman, A. (2003). In Equal Measure, Addressing the broad spectrum of indoor environmental quality in school and university buildings. American School and University (Asumag), 34-41. In 16 November 2020 Available from website: https://www.asumag.com/mag/article/20849740/in-equal-measure

GRHC -Green Roofs for Healthy Cities. (2008). Introduction to Green Walls Technology, Benefits \& Design. Reported by Green Roofs for Healthy Cities, 5-12.

Haggag, M. Hassan, A. Elmasry, S. (2014). Experimental study on reduced heat gain through green facades in a high heat load climate. Energy and Buildings. Elsevier Journal, 82, 668-674.

Helzel, M. (2012). Paslanmaz Çelikten Yapılmış Yeşil Duvarlar. Belgium, Euro Inox Press, 17(1), 19.

Khabbazi, A. P. and Erdoğan, E. (2013). Yapı Yüzeylerinde Bitki Kullanımı: Dikey Bahçeler ve Kent Ekolojisi. Türk Bilimsel Derlemeler Dergisi, 6 (1), 23-27.

Manson, M. and Castro Gomes, J. (2014). Green wall systems: A review of their characteristics. Renewable and Sustainable Energy Reviews. Elsevier Journal, 41, 863-871.

McCullough, M.B. Martin, M.D. Sajady, M.A. (2018). Implementing Green Walls in Schools. Frontiers in Psychology, 9, 619.

MEGEP, (2016). Dikey Bahçeler. Vocational and Technical Education Program, 18-20. [PDF document]. In 21 November 2020 Available from website: http://megep.meb.gov.tr/mte_program_modul/moduller/Di key\%20Bah\%C3\%A7eler.pdf

Mendler, F. S. and Odell, W. (2000). The Hok Guide Book to Sustainable Design. John Wiley\&Sons, New YorkUSA, 1, 5-17.

Merriam-Webster Inc. (2002). The New Webster Dictionary of the English Language. Dictionary. 10. Press.

Mir, M.A. (2011). Green Facades and Building Structures. (MSc Thesis). Delft University of Technology, Delft, Holland, 119.

Murphy, C. and Thorne, A. (2010). Health and Productivity Benefits of Sustainable Schools: A Review. Bre Group Press, 3-6.

Ottele, M. (2011). The green building envelope vertical greening. (Unpublished Doctoral Thesis). Delft University of Technology, Delft, Holland, 11-17.

Örnek, M.A. (2011). A Case Based Design System Purpose for Using in Vertical Garden Design Process. (MSc Thesis), Istanbul Technical University, İstanbul, Turkey, 36-37.

Pan, X. and Xiao, Y. (2014). Simulation Analysis of Building Green Facade Eco-Effect. Applied Mechanics and Materials, 548-549, 1701-1705.

Papadopoulou, G. (2013). Green Walls as element of bioclimatic design in Mediterranean Urban Buildings. (MSc Thesis). International Hellenic University, Selanik, Greek, 11-25, 49.

Perini, K. Ottele, M. Haas, E. M. Raiteri, R. (2013). Vertical greening systems and a process tree for green façades and living walls. Urban Ecosystems, 16, 265-277.

Sylvan, R. and Bennett, D. (1994). The Greening of Ethics. Cambridge: White Horse Press and Tucson: The University of Arizona Press, 206-207.

Şahin, E.B. and Dostoğlu N. (2015). Okul Binaları Tasarımında Sürüdürülebilirlik. Uludağ University Journal of the Faculty of Engineering, 20(1), 76-77.

Url- 1: https://www.flickr.com/photos/74068756@N00/22150821/ (Date of access: 15.08.2020)

Url-2: https://sqrfactor.com/post/post-detail/green-wall-technologies-8893 (Date of access: 15.08.2020)

Url-3: https://omrania.com/insights/green-walls-how-technology-brings-nature-into-architecture/ (Date of access: 05.06.2020)

Url-4: https://www.installitdirect.com/learn/how-to-build-a-pocket-garden/ (Date of access: 03.10.2020)

Url-5: http://architizer.com/projects/aeronautical-cultural-center/ (Date of access: 30.09.2020)

Url-6: https://www.architonic.com/ (Date of access: 28.09.2020)

Url-7: https://www.worldarchitecturenews.com/ (Date of access: 03.10.2020)

Url-8: https://green-walls.co.uk/projects/view/curtain-green-wall/curtain-green-wall-6/ (Date of access: 03.10.2020)

Url-9: https://i.pinimg.com/originals/6c/e1/e9/6ce1e9e819f85d3f1c9426bba4078b6d.jpg (Date of access: 04.10.2020)

Url-10: https://realtybiznews.com/can-growing-plants-on-your-walls-really-benefit-yourproperty/98733406/ (Date of access: 28.09.2020)

Url-11: https://www.architonic.com/en/product/carl-stahl-arc-x-tend-facades/1184961 (Date of access: 29.09.2020)

Url-12: https://www.greenovergrey.com/green-wall-benefits/energy-savings.php (Date of access: 30.09.2020) 
Url-13: https://www.greenroofs.com/projects/drew-school-sam-cuddleback-iii-assembly-wing-verticalgarden/ (Date of access: 12.04.2020)

Url-14: https://www.archdaily.com/217481/school-of-the-arts-woha (Date of access: 30.10.2020)

Url-15: https://www.ansgroupglobal.com/living-wall/case-studies/university-leicester (Date of access: 30.10.2020)

Url16: https://tr.wikipedia.org/wiki/Adana\%27da_2007_T\%C3\%BCrkiye_genel_se\%C3\%A7imleri\#/media/ Dosya:Adana_in_Turkey.svg (Date of access: 30.10.2020)

Url-17: https://www.cu.edu.tr/cu/institutional/university/fotograf-galerisi (Date of access: 30.10.2020)

Url-18: https://www.archweb.it/dwg/Giardini_verticali/giardini_verticali_su_muro.html (Date of access: 30.10.2020)

Zarandi, M. M. and Pourmousa, M. (2018). A comparative study on details of green walls in different climates. Environmental Resources Research, 6 (2), 191-193.

\section{Resume}

Ülkü Şimşek is a graduate of Çukurova University Faculty of Architecture, Department of Architecture. She completed his master's degree at Çukurova University Faculty of Architecture in 2020. She worked in an office as an architect from 2017 to 2020. Her special interests and research interests are sustainable architecture and energy efficient design.

Özlem Şenyiğit is an Assistant Professor in the Faculty of Architecture at Çukurova University, Adana. She received her PhD in the Faculty of Architecture at Yildiz Technical University, istanbul in 2010. Her special fields of interest and research is basic design, image, visual perception, visual communication in design. Şenyiğit has published many proceedings, articles and book chapters about her research areas. 